DOI: https://doi.org/10.15688/lp.jvolsu.2017.3.10

UDC 316

LBC 60.56

\title{
THE REVOLUTIONARY 1917 YEAR IN POSTER IMAGES ${ }^{1}$
}

\author{
Nadezhda A. Zinovyeva \\ Sociological Institute of the Federal Sociological Research Center of RAS, \\ Saint-Petersburg, Russian Federation
}

\begin{abstract}
In 1917 a political poster becomes an important source for the formation of mass consciousness. The article discusses the social conditions and causes of a poster campaign, analyzes the artistic content and characteristics of the early revolutionary posters. Among the conditions under which there was political agitation of the time, the author identifies censorship, high prices, dominance of text forms (books, Newspapers, leaflets, banners), limited agitation of the urban area. Confusion and rapid change of events after February revolution has spawned the need to create new dynamic ways of influencing the masses, political posters played a special role.

The author identifies the genre features of the classical Russian political posters and compares them with the characteristic features of posters in 1917. Among the art features the author notes the lack of own poster style. The poster is created from the clichŭs born of book and newspaper illustrations, advertisements, which change under the new political tasks. Communicative-informative features include the fact that the posters often tell or show the new world order not calling for action. The clarity and consistency of involved ideas is often achieved not by the images but at the expense of the text printed on the posters. The text is primary in relation to the image, and sometimes is not easy to read and understand. However by the end of the year the posters are able to develop their own symbolism (images of the rising sun, broken chains, red flags, etc.), recognizable images (the oppressed and heroic workers, soldiers, peasants, priests thick, generals ringing orders, "kulaks" sitting on bags) and their own ways of conveying ideas.

Key words: political poster, poster campaign, revolution of 1917, art peculiarities of posters, content and communicative characteristics of posters.
\end{abstract}

УДК 316

ББК 60.56

\section{РЕВОЛЮЦИОННЫЙ 1917 ГОД В ПЛАКАТНЫХ ОБРАЗАХ ${ }^{1}$}

\author{
Надежда Андреевна Зиновьева \\ Социологический институт Федерального научно-исследовательского социологического центра РАН, \\ г. Санкт-Петербург, Российская Федерация
}

\begin{abstract}
Аннотация. В 1917 г. важным источником формирования массового сознания становится политический плакат. В статье рассматриваются социальные условия и причины возникновения плакатной агитации, анализируются художественные и содержательные особенности ранних революционных плакатов. Среди условий, в которых происходила политическая агитация того времени, автор выделяет цензурирование, дороговизну, доминирование текстовых форм (книги, газеты, листовки, транспаранты), ограниченность агитации городской территорией. Неразбериха и высокая скорость смены событий после Февральской революции породили необходимость создания новых динамичных способов воздействия на массы, особую роль играли политические плакаты.

Автор выделяет жанровые особенности классического русского политического плаката и сравнивает их с характерными чертами плакатов 1917 года. Среди художественных особенностей автор отмечает отсутствие собственного плакатного стиля. Плакат создается из клише, выработанных книжными и газетными иллюстрациями, рекламными объявлениями, которые переделываются под новые политические задачи. Коммуникативно-содержательные особенности заключаются в том, что плакаты чаще повествуют или демонстрируют новый миропорядок, а не призывают к активным действиям. Ясность и непротиворечивость заключенных идей часто достигается не благодаря изображению, а за счет напечатанного на плакатах текста. Текст,
\end{abstract}


как правило, выступает первичным по отношению к изображению и порой неудобен для чтения и восприятия. Однако к концу года в плакатах удается выработать собственный символизм (образы восходящего солнца, разорванные цепи, красные флаги и пр.), узнаваемые образы (угнетенные или героические рабочие, солдаты, крестьяне, толстые попь́, звенящие орденами генералы, сидящие на мешках «кулаки») и собственные способы донесения идей.

Ключевые слова: политический плакат, плакатная агитация, революция 1917 г., художественные особенности плакатов, содержательно-коммуникативные особенности плакатов.

\section{Введение}

В истории русского политического плаката 1917 год примечателен тем, что это был период, когда пропаганда посредством политического плаката активно институционализировалась, формировался особый язык, нарабатывались визуальные шаблоны. Гражданская война, разделившая страну на «белых» и «красных», подстегнувшая развитие плакатной агитации, не началась, поэтому плакаты еще не клеймят две народные силы. Страна пока едина, противоречия только начинают артикулироваться, и плакаты пока еще только становятся одним из основных средств агитации. Как правило, исследователи уделяют больше внимания разностороннему анализу особенностей более поздних, жанрово сформировавшихся плакатов. Тем не менее сохранившиеся экземпляры плакатов 1917 г. обладают глубиной и своеобразием, ведь наряду с клише, наработанными в других медиа-формах, велись творческие поиски собственных способов выражения идей и воздействия на зрителя. Анализ плакатов 1917 г. позволяет выявить их характерные художественные и содержательные особенности, вносит вклад в исследование социальной реальности революции и зарождающегося гражданского конфликта.

Целью данной статьи является выявление художественных (форма) и содержательно-коммуникативных (содержание) особенностей плакатов 1917 года. Для этого анализируется изобразительная продукция 1917 г., выделяются ее характерные черты и сопоставляются с известными жанровыми чертами более поздних политических плакатов времен революции и Гражданской войны. Эмпирической базой послужили пропагандистские материалы 1917 г., опубликованные в работах по истории плаката [3].

\section{Основные характеристики плаката как средства коммуникации}

Плакат - это «броское изображение на крупном листе с кратким пояснительным текстом, выполняемое в агитационных, рекламных, информационных или учебных целях» [9]. Политический плакат представляет собой вид изобразительного искусства, выполняющий функцию наглядной политической агитации, служащий средством информации, рекламы, инструктажа. Он нацелен на решение политических и социальных задач, актуальных в какой-либо исторический момент. Одной из основных функций политического плаката является символическая репрезентация власти. Она осуществляется для того, чтобы продемонстрировать основы существующего (а в рамках рассмотрения темы революции - победившего) миропорядка или чтобы побудить реципиента на активную деятельность во имя этой власти.

Характерными чертами политического плаката являются ограниченное время его создания художником и краткое время для восприятия плаката реципиентом. Первое диктуется тем, что плакат создается «на злобу дня», то есть в ответ на актуальные политические и социальные запросы, поэтому затягивание процесса его создания ведет к изменению ситуации и потере интереса публики. Второе краткое время восприятия - объясняется тем, что политический плакат рассчитан на массовую агитацию в пространстве города. Зритель видит его между делом, спеша по своим делам, и если плакат не «зацепляет», не останавливает на себе внимание, то остается незамеченным.

Обозначенные характерные черты диктуют стилистические особенности политического плаката - а именно своеобразные требования к содержанию и форме. Требования к содержанию: ясность, непротиворечивость 
заключенной идеи, простота, понятность, яркость используемых образов [5]. Плакат должен быть таким, чтобы идею, заключенную в нем, мог понять даже необразованный человек, и понять с первого взгляда, не задерживаясь долго у плаката. Кроме того, плакат должен обладать привлекающей внимание драматургией (то есть продуманной сюжетно-образной концепцией), сюжетностью, поясняющей социальную проблему и возбуждающей желание действовать. Тогда он не останется незамеченным и будет транслировать заложенный смысл.

Требования к форме: выразительные черты используемых персонажей, яркие цвета, связанность текста и изображения, сокращение глубины пространства, ограниченность количества используемых цветов (диктуемое использованием печатной полиграфии), большеформатность. Эти требования помогают донести заложенную идею максимально просто, быстро, а также влияют на упрощение массового производства. Чем меньше цветов и чем проще используемые формы, тем меньше искажений произойдет в ходе массовой печати и тем меньше прокатов полиграфической машины понадобится, что ускорит и удешевит печать. В.П. Полонский - советский критик, историк, написавший в 1925 г. книгу, посвященную революционным плакатам «по горячим следам», пишет: «Экономия - прежде всего. Плакат является живописным выразителем формулы, которой подчинена вся коммерческая, торгово-промышленная жизнь индустриальных стран: “время - деньги”» [7, c. 8]. Он описывает особенности плаката следующим образом: «Он [плакат] не требует детализации. Предмет в плакате трактуется схематически. Форма подчеркивается основными линиями, резкими и глубокими. Расцветка - красками чистыми, насыщенными, без полутонов, нюансов, оттенков - сплошными заливками» [7, с. 8]. Кроме того, учитывая социальный контекст 1917 г., изображение на плакате должно было восприниматься и без текста, поскольку далеко не все реципиенты были грамотными.

Все перечисленные стилистические особенности формы и содержания позволяют отнести политический плакат к новому жанру искусства, проявившему себя в условиях мас- сового общества. А для социальных исследователей политический плакат - это дискурс, позволяющий интерпретировать ключевых социальных акторов эпохи. Перечислим еще раз основные жанровые особенности классического русского революционного плаката.

Содержательно-коммуникативные особенности:

- идея должна быть выражена понятно и непротиворечиво;

- используемые образы должны быть узнаваемы;

- изображение должно обладать своей драматургией, сюжетностью, динамикой;

- плакат должен описывать новый миропорядок и/или призывать к активным действиям;

- текст и изображение должны составлять идейное единство.

Художественные особенности:

- плакат должен быть ярким, «зацепляющим» внимание;

- ограничение по количеству цветов и художественных изысков: теней, полутонов и мелких деталей;

- сокращение глубины пространства, ограничение количества планов изображения;

- персонажи должны обладать характерными чертами, быть узнаваемыми;

- большеформатность.

Характерные художественные формы и способы отражения идей, а также новые социальные задачи, стоящие перед политическим плакатом, позволяли этому новому жанру искусства выйти на улицы из музеев и картинных галерей и стать «орудием массового внушения, средством организации коллективной психологии» [7, с. 14].

Однако в 1917 г. жанр политического плаката был еще в стадии формирования. Обратимся к анализу того, как в год двух революций шло становление плакатных форм убеждения. Фокус нашего внимания обращен на политические-пропагандистские, агитационные - плакаты, распространявшиеся в 1917 году.

Каков социально-исторический контекст, повлиявший на формирование политического плаката того времени? В дореволюционный период партийная политическая пропаганда и агитация развивались в специфических условиях. Первым важным фактором явилось то, 
что агитационная продукция была в основном печатной, в форме книг, журналов, газет, прокламаций. Плакаты использовались сравнительно мало. Доминирование текстовой пропаганды предполагало, что она будет воспринята теми, кто умел читать. Согласно данным переписи, грамотных людей в России к 1913 г. было 24-25 \% сельского и 38,8-66,9 \% (в зависимости от города) городского населения [8], то есть о массовости реципиентов-читателей речи не шло. Вторым важным фактором было то, что такая печатная массовая агитация подлежала цензуре. Следовательно, к ней могли официально прибегать только правительство и легальные партии. Нелегальные же партии могли использовать только подпольные издания, тираж которых был небольшим, а распространение затруднено. Кроме того и это третий важный фактор - стоимость производства агитационных материалов была высокой. Для массовой печати полиграфической продукции требовались цветные литографические машины, которыми располагали не многие типографии. Владельцы типографий могли ставить любые цены и даже выбирать, с кем сотрудничать. И они отдавали предпочтение легальным и богатым партиям. Четвертым фактором мы можем назвать то, что территориально печатная пропаганда была ограничена пространством городов. Причинами тому были и массовая неграмотность деревенского населения, и трудности с транспортировкой. Обзор условий приводит нас к выводу, что о доступности и массовости пропаганды речи идти не могло, а плакатная агитация в начале $\mathrm{XX}$ в. была делом сложным и многозатратным.

Февральская революция, как и всякая быстрая смена власти, во многом стихийно произошедшая, привнесла хаос и подорвала привычные каналы обмена информацией. События развивались очень быстро. Книги и журналы не успевали печататься и читаться, а листовки не имели воздействия на стихийно собирающиеся толпы рабочих. Возникла необходимость создания новых способов воздействия на массы и развития новых каналов передачи и получения информации. В период между Февральской и Октябрьской революциями 1917 г. для этих целей широко использовались лозунги и транспаранты, что тоже, по сути, яв- ляется продолжением традиции печатного слова, только приобретшего более лаконичную форму, написанного большими буквами и перенесенного на улицы. Однако запрос на создание более эффективных, быстрых, ярких и запоминающихся средств информирования и воздействия оставался. Это и подготовило благодатную почву для появления и распространения политического плаката.

Знаковым моментом осознания и реализации идеи массового производства плакатов можно назвать 28 марта 1917 г. [6], когда в газете «Русская Воля» было напечатано весьма характерное обращение: «Товарищи! Петроградские деятели искусств - художники, поэты, писатели, актеры и музыканты образовали общество “На революцию” с целью помочь революционным партиям и организациям в проповеди революционных идей путем искусства. Товарищи, - если вы хотите, чтобы ваши манифестации, плакаты и знамена были заметней, - дайте вам помочь художникам...» [4, с. 124]. И этот призыв был услышан. Стали активно создаваться и массово распространяться формы изобразительного искусства, аналогичные ежедневной газете и листовке по динамике, полемичности, злободневности, а именно: плакат, открытка, листовка, лозунг, карикатура [2, с. 51]. Итак, плакаты попали в массовое производство и распространение.

Политические плакаты 1917 г. можно условно разделить на три группы на основе их содержания: партийная агитация, военно-экономическая агитация («Заем Свободы») и революционная пропаганда. Проанализируем характерные художественные и содержательнокоммуникативные особенности плакатов каждой группы.

\section{Развитие плакатов, посвященных партийной агитации в 1917 году}

Предвыборная кампания в Учредительное собрание была ознаменована появлением печатных агитационных плакатов, однако выглядели они довольно просто, содержали название партии, призыв голосовать за список партии и минимальное художественное оформление. В.П. Полонский отмечает, что «по количеству, качеству, размерам и богатству 


\section{СОЦИОЛОГИЯ И СОЦИАЛЬНЫЕ ТЕХНОЛОГИИ}

красок первое место занимают литографии партии С.-Р. Следом за ними идут плакаты крупной буржуазии (К. Д., торгово-промышленная партия, комитет мелкой и средней промышленности). Последнее место занимают небольшие по размерам, в небольшом количестве экземпляров изданные, с наименьшим числом красок изготовленные плакаты социал-демократических партий» $[7$, с. 22]. Немаловажное, на наш взгляд, влияние оказали названные выше экономические причины: чем больше в плакате использовалось цветов, тем больше прокатов типографической машины требовалось, и тем дороже получалась печать.

Искусство формулирования и трансляции политических и социально-мировоззренческих идей через плакаты было еще в самом начале своего развития, поэтому визуализации идей еще не придавалось большого значения. Плакаты «Выбирай Социалистов-революционеров» (Неизвестный художник, 1917 г.) [1, c. 44] и «Все сознательные граждане Российской республики голосуют...» (Неизвестный художник, 1917 г.) [1, с. 42] - примеры такого оформления. Можно видеть следующие содержательно-коммуникативные особенности этих плакатов: ясность и непротиворечивость заключенной идеи достигается за счет напечатанного на плакатах текста; текст призывает к активным действиям - а именно проголосовать за ту или иную партию; образ лубочного солнца на первом плакате и карта «Российской республики» на втором - узнаваемы, однако не связаны ни с текстом, ни с идеями плакатов; сюжетность отсутствует.

Художественные особенности: плакат «Выбирай Социалистов-революционеров»-яркий, пытается зацепить внимание своим многоцветием; на плакате присутствует ограниченное количество цветов (четыре) и нет теней, полутонов, а также всего один план изображения. На плакате «Все сознательные граждане Российской республики голосуют...» используется три цвета, нет художественных изысков, он смотрится бледным, кроме того, он перегружен текстом.

Таким образом, особенностью этих плакатов является то, что основная идейная нагрузка ложится на текст. Изображение второстепенно, оно не связано напрямую с текстом, используется для привлечения внимания.

Однако даже при наличии денег и художественных возможностей существовала проблема, что именно изображать, как донести политические идеи и какие именно идеи нужно доносить в плакате. Поиски емких и понятных символов и аллегорий не всегда венчались успехом. Попытка воспользоваться приемом символизации была сделана, например, на плакате «кадетов» «Анархию победит демократия» (рис. 1) (Петроград, Изд-во Комитета средней и мелкой промышленности, 1917 г.) или на плакате с маяком «Р.С-ДР.П. Голосуйте за список № 1» (Петроград, Тип. «Копейка», 1917 г.).

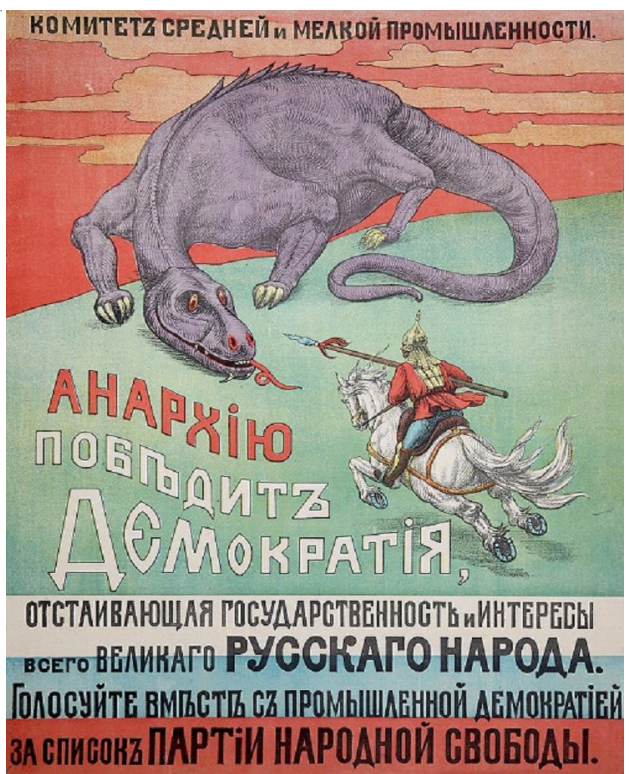

Рис. 1. Плакат «Анархию победит демократия» (Петроград, Изд-во Комитета

средней и мелкой промышленности, 1917 г.)

Содержательно-коммуникативные особенности плакатов. На плакате «Анархию победит демократия» лубочный образ борьбы витязя и змия призван был символически показать борьбу демократии и анархии, однако, чтобы это понять, плакат пришлось перегрузить пояснительным текстом; сам текст остается первичным по отношению к изображению, его слишком много, он не «высушен» до одной и ясной идеи; образы узнаваемы, изображение обладает внутренней сюжетностью, драматургией, однако не связано с текстом напрямую, может быть использовано, например, как книжная иллюстрация к 
былине. Плакат имеет целью призвать реципиентов к активным действиям, а именно голосовать за «кадетов», однако это следует только из последней строчки, что затрудняет понимание. На плакате «Р.С-ДР.П. Голосуйте за список № 1» изображение (маяк в бурном море) так же лишь очень условно связано с текстом, оно не выражает специфики идеологии партии РСДРП, не обладает сюжетной драматургией. Текст же содержит призыв голосовать и выполняет смыслообразующую функцию.

Художественные особенности плакатов: плакат «кадетов» яркий, художественный, стилизован под лубочную картину, привлекательный; плакат партии РСДРП выполнен в художественном стиле графики; однако он не перегружен текстом, и текст, несущий идею, выделен красным, поэтому хорошо читается; тем не менее в условиях города он смотрится блекло, не зацепляет внимание. Изображения на обоих плакатах по-своему концептуальны и привлекательны, однако плохо связаны с текстом и с основной идеей.

Судя по сохранившимся плакатам, дальше всех других партий в оформлении пошла партия социалистов-революционеров (эсеры). Их идеологи сотрудничали с художниками и уже тогда вели поиск ярких образов. Плакат с солнцем («Выбирай Социалистов-революционеров») интересен тем, что он исполнен в ярких цветах, имеет мало текста и использует образ лубочного солнца, создающего настроение близости к народу. Однако изображение дается «для красоты» и не содержит призыва, не обладает сюжетной динамикой.

Следующий плакат эсеров - плакат «Земли и воли даст вам список Совета Крестьянских Депутатов и партии Социалистов Революционеров» (рис. 2) (Неизвестный художник, 1917 г.) изображает девушку-крестьянку в народном костюме, что вновь призвано подчеркнуть связь с народом. Его содержательно-коммуникативные особенности: изображение статично, девушка безэмоциональна, больше напоминает рекламный манекен, чем живого человека; идейная нагрузка вновь приходится на текст. Текста много, и он призван донести центральную идею партии. Однако изображение не отражает идеи «Земли и воли», и при желании текст мог бы быть заменен на любой другой, например на стихи о Родине или рекламу швейной фабрики. Через текст осуществляется и призыв к активным действиям - голосовать за эсеров. Текст и изображение не связаны, кроме того, текст избыточен.

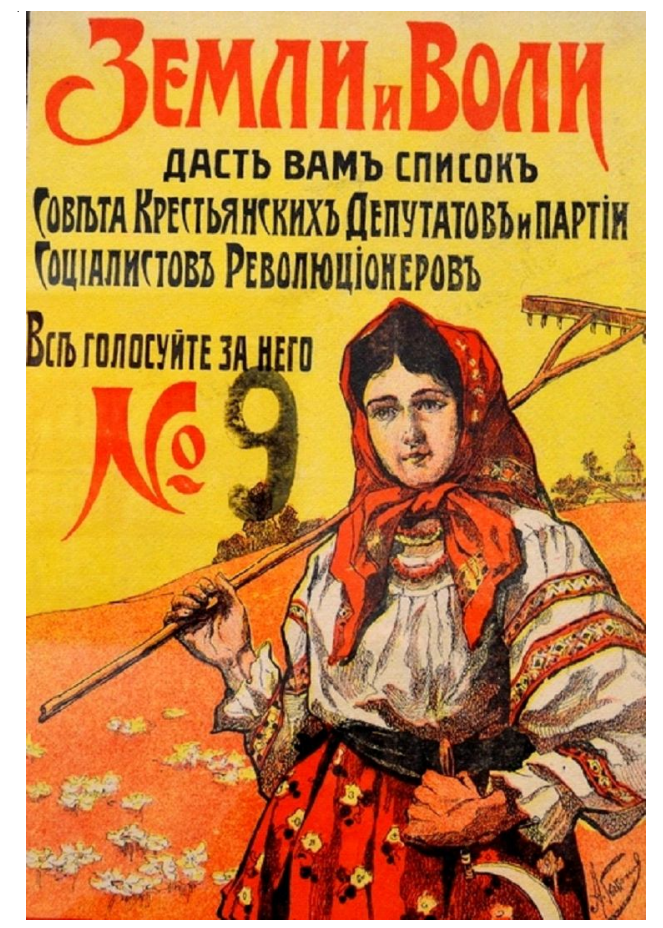

Рис. 2. Плакат «Земли и воли даст вам список Совета Крестьянских Депутатов и партии Социалистов Революционеров» (Неизвестный художник, 1917 г.)

Художественные особенности плака$m a$ : плакат яркий, художественный, явно создан по мотивам рекламы или книжных иллюстраций; используется много цветов, тени, несколько планов изображения, уделено внимание прорисовке деталей. Персонаж - крестьянка - узнаваемый, однако слабо связан и со зрителями-горожанами, и с реальными крестьянами. Таким образом, плакат художественный, яркий, однако изображение не выражает идеи и не связано с текстом.

Плакат «Партия соц.-рев. В борьбе обретешь ты право свое» (Неизвестный художник, 1917 г.) [1, с. 40] тех же эсеров уже является попыткой сделать средство, действительно побуждающее к действию. Содержательно-коммуникативные особенности плака$m a$. В изображении есть своя драматургия: фигуры динамичны, застыли в движении, центральная фигура явно изображает призыв. Перспектива выстроена таким образом, что изоб- 
ражение и зрителя разделяет земной шар, а центральная фигура зовет за собой толпы борцов. Каждый зритель ставится перед идущей на него толпой, перед выбором присоединиться к большинству и бороться за «Землю и волю» во всем мире или остаться в одиночестве и позорно сбежать. Центральная фигура хоть и не смотрит на зрителя, но не безлика и узнаваема. Одежда выдает человека того времени, горожанина, рабочего. Таким образом, эсеры меняют «целевую аудиторию» с народа вообще (плакат с солнцем) на крестьян (плакат с крестьянкой) и теперь на пролетариев. Есть символизм - разорванная цепь, означающая снятие «оков рабства», земной шар, говорящий о глобальности революции, - для разгадывания которого не нужна длительная работа публики. Красный флаг и слова на нем «В борьбе обретешь ты право свое» отражают девиз партии, а надпись «Земля и воля» на земном шаре показывает результат этой борьбы в масштабах всего мира. Все это отражает идеологию партии социалистов-революционеров. Плакат не перегружен текстом, сделана попытка гармонично вплести слова в изображение.

Художественные особенности. По форме - плакат яркий, привлекает внимание динамичностью изображения. Черты персонажей выразительные, узнаваемые. Есть несколько планов изображения, тени, тщательная прорисовка фигур и деталей, что противоречит выделенным ранее характеристикам «жанрового» плаката. Но, несмотря на это, данный плакат уже попадает в стилистику за счет адекватного изображения идеи.

Обзор предвыборных плакатов позволяет сказать, что, несмотря на высокую стоимость производства плакатов, необходимость говорить с избирателями на языке понятных им визуальных образов в 1917 г. была осознана. Однако для этого использовались образы и стилистика, почерпнутые из других сфер - из коммерческой рекламы, книжных иллюстраций, художественных картин. Текстовая часть, как правило, выступала первичной по отношению к изображению. Перегруженность текстом, с одной стороны, и весьма условная связь изображения и текста - с другой затрудняли понимание плаката.
Развитие плакатов,

\section{посвященных военно-экономической агитации в 1917 году}

Кроме предвыборных, в 1917 г. распространялись плакаты Временного правительства, посвященные военно-экономической агитации, а именно военному займу, «Займу Свободы». Их целью был призыв населения жертвовать деньги на продолжение войны. Среди них - знаменитый плакат «Заем Свободы» Б.М. Кустодиева (1917 г.) и плакат «Подписывайтесь на Заем Свободы. Родина и свобода в опасности...» А.И. Кравченко (1917 г.)

Эти плакаты обладают художественной ценностью, в них используется множество цветов, тонов и полутонов, они яркие и красивые. Это говорит о том, что на создание таких плакатов денег не жалели, что входит в диссонанс с целью создания плакатов - сбором денег. Фигуры на плакатах статичны и не обращаются к зрителю. Одежда изображенных на обоих плакатах людей выдает в них военных, однако они не производят впечатления защитников: на плакате А.И. Кравченко значимость фигур размывается агрессивноярким фоном. Кроме того, плакат перегружен в цветовом и композиционном решении: изображение содержит множество деталей, используются яркие, почти агрессивные цвета. На плакате Б.М. Кустодиева солдат стоит на фоне людей, идущих с флагами мимо него. Как соотносятся эти люди, идущие своей дорогой, и этот солдат, стоящий над ними, спиной к ним и пребывающий в задумчивом спокойствии, не понятно. Далее плакат «Подписывайтесь на Заем Свободы. Родина и свобода в опасности...» перегружен текстом, на плакате «Заем Свободы» текста мало, однако изображения на обоих плакатах связаны с текстом очень опосредованно.

Содержательно-коммуникативные особенности. Образы военных узнаваемы, однако динамизм и сюжетность отсутствуют. Текст выступает первичным по отношению к изображению, поясняет его. Призыв содержится только в тексте, причем только в плакате «Подписывайтесь на Заем Свободы. Родина и свобода в опасности...». Идею-призыв плаката «Заем Свободы» никак не поясняет ни текст, ни изображение. 
Художественные особенности плакатов. Фигуры обладают выразительностью, цвета используются яркие, перспектива упрощена. Однако изображения излишне богаты художественно (тона, полутона, тени), множество деталей, ярких цветов. Все это позволяет скорее отнести изображения к жанру изобразительного искусства, к картинам, чем к жанру плаката.

Можно заключить, что плакаты военноэкономической агитации еще не отходят от книжных и рекламных клише. Они яркие, богатые художественно, но не идейно. Изображение и текст связаны очень опосредованно.

\section{Развитие плакатов, посвященных} революционной пропаганде в 1917 году

Третью группу плакатов, распространяющихся в 1917 г., мы назвали «революционная пропаганда», поскольку основной идеей, заложенной в них, было прославление революции и ее результатов. Плакаты разные по стилистике и выразительным средствам.

В плакатах широко используются клише, почерпнутые из газет. Например, иллюстрация, передающая факты, - плакат «Дни революции в Москве 2 марта на Воскресенской площади» (Москва, Литография тов-ва И.Д. Сытина, 1917 г.) (рис. 3). Или демонстрация портретов людей, стоящих во главе государства после Февральской революции, - плакат «Великое освобождение России» (Москва, Изд-во Г. и Д. Александровых, 1917 г.).

Содержательно-коммуникативные особенности плакатов. На плакате «Дни революции в Москве 2 марта на Воскресенской площади» изображение реалистично, погружает зрителя в происходящее событие, позволяет увидеть его собственными глазами. Идея плаката «Великое освобождение России» состоит в демонстрации портретов членов Временного правительства, а также воспевании Февральской революции как освобождения России. Таким образом, идеи на обоих плакатах отражены ясно и непротиворечиво; изображения сюжетны, динамичны. Газетная реалистичность воплощается на плакатах поразному: плакат «Дни революции в Москве 2 марта на Воскресенской площади» демонстрирует реалистичность событий, однако не использует узнаваемые образы; плакат «Великое освобождение России» демонстрирует портреты реальных людей и использует узна-

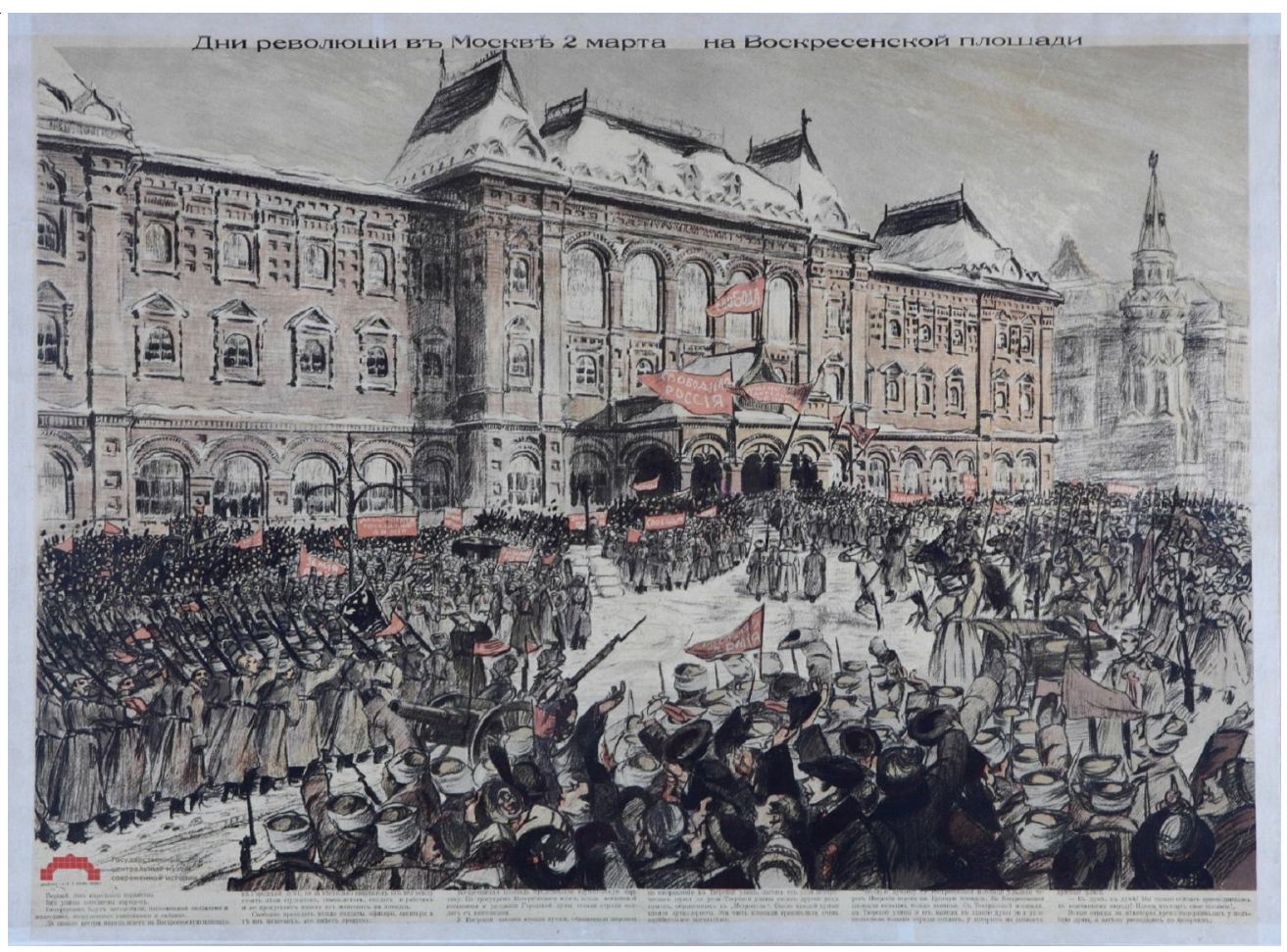

Рис. 3. Плакат «Дни революции в Москве 2 марта на Воскресенской площади» (Москва, Литогр. тов-ва И.Д. Сытина, 1917 г.) 
ваемые образы (крестьян, рабочих, военных), однако сюжет фона - не реалистичен. Текст играет скорее поясняющую, второстепенную роль, частично включен в изображение: лозунги искусно вписаны во флаги, подписи под портретами поясняют, кто на них изображен. Оба плаката ни к чему не призывают, но прославляют новый мир, эмоционально воздействуют на зрителя.

Художественные особенности плакатов. На обоих плакатах изображения содержат множество мелких деталей: масса людей с красными флагами; выстроена перспектива, используется множество полутонов; присутствует разделение на несколько планов. Создание плакатов наверняка заняло много времени и сил, кроме того, все перечисленные детали не удобны для печати. Плакаты не яркие, не броские.

Таким образом, использование газетных клише обогащает жанр плакатов реалистичностью, заставляющей зрителя сопереживать и быть в курсе происходящих событий. Однако художественные недостатки (неяркость, множество деталей) не позволяют в полной мере использовать преимущества плакатного жанра.

Для прославления наступления нового миропорядка в 1917 г. используются образы победителей - солдат, рабочий; часто подчеркивается их содружество. Примерами могут служить плакаты «Да здравствует свободная Россия!» А.М. Зальцмана (1917 г.) и «Памятка народной победы. Николай Романов отдает корону своим победителям» (Петроград, Невская художественная электропечатня, 1917 г.)

Содержательно-коммуникативные особенности плакатов. На плакатах присутствуют узнаваемые образы «рабочего» и «солдата», чье содружество в революции сделало возможным начало новой эры. Наступление нового миропорядка и надежду на счастливое будущее символизирует восходящее солнце. На плакате «Памятка народной победы...» к этим образам добавляется коленопреклоненный император Николай Романов, передающий корону и символически власть. Таким образом, идеи победоносного сотрудничества и символической передачи власти выражены ясно. Изображения сюжетны, на- полнены символизмом, но статичны. Плакаты не призывают к действиям, но демонстрируют наступление новой жизни. Текст и изображение на обоих плакатах являются взаимодополняющими.

Художественные особенности плакатов. Плакат «Да здравствует свободная Россия!» исполнен в черно-белой гамме, в технике «графика», его нельзя назвать ярким, однако лаконичность сюжета делает его понятным и «зацепляющим». Напротив, плакат «Памятка народной победы...» - многоцветный, яркий, однако множество символов и деталей уводит внимание от основного сюжета.

Таким образом, плакат обогащается узнаваемыми собирательными образами, обладающими характерными деталями одежды, символами новой эпохи - восходящим солнцем и красным знаменем.

На плакате «Самодержавный строй. Мы царствуем. Мы за вас молимся. Мы вас судим. Мы вас охраняем. Мы вас кормим. А вы работайте!» А. Радакова (см. рис. 4) (Петроград, изд-во «Парус», 1917 г.) необходимо остановиться отдельно. Он создан в форме «социальной пирамиды». Пирамида, как комикс, содержит несколько уровней-сюжетов, которые можно рассматривать и по отдельности, и в комплексе. Все сюжеты динамичны, демонстрируют ущемление прав трудящихся, скрывающееся за декларируемыми текстовыми лозунгами. Этот плакат особенно примечателен тем, что на нем зарождаются образы для агитплакатов следующих лет толстые попы', злые генералы, звенящие орденами, толстые, сидящие на мешках «кулаки» с одной стороны и угнетенные крестьяне, рабочие и солдаты - с другой.

Содержательно-коммуникативные особенности плаката. Идея плаката - отразить социальную пирамиду во всей ее несправедливости - ясна. Плакат преисполнен символичности. Характерные черты каждого из образов гиперболизированы, поэтому образы яркие и узнаваемые. Каждый из изображенных сюжетов обладает своей динамикой и драматургией. Даже царь, который изображен один, преподносится в процессе, в динамике: он «царствует». Его накидка фактически и символически «покрывает» все происходящее, является контуром, удерживающим 
пирамиду в насущном состоянии, а творящееся беззаконие - в процессе. Текст органично вплетается в изображение и становится его важной смысловой частью, позволяющей продемонстрировать диссонанс между тем, что провозглашается, и реальным положением дел. Текст и изображение составляют единое целое. Плакат напрямую ни к чему не призывает и не демонстрирует новое положение вещей. Он обращается к эмоциям зрителя в надежде, что продемонстрированные образы вызовут в нем несогласие и спровоцируют активные действия для перестройки существующей пирамиды, однако об этом должен догадаться сам реципиент.

Художественные особенности плакаma. Плакат яркий, многоцветный, зацепляющий внимание своей необычной формой. Используется много цветов и мелких деталей, однако нет теней, полутонов и размытой толпы. Все образы персонифицированы. Большеформатность играет на руку изображению: детали становятся более крупными и удобными для восприятия. Глубина пространства сокращена до единственного плана изображения и фона с облаками, не несущего сюжетной нагрузки.

Таким образом, этот плакат - один из немногих плакатов, который обладает почти всеми признаками русского революционного плаката. Он яркий по форме и глубокий по содержанию. Единственное, что на нем отсутствует - это внятный призыв к активным действиям. Реципиенту демонстрируется пирамида несправедливости и оставляется свобода выбора - что думать и как жить дальше. Позже политические плакаты не стали давать зрителям возможности домыслить, прибегая к конкретным призывам.

Подводя итог, отметим, что плакаты, которые можно отнести к тематике революционной пропаганды, пошли дальше других в искусстве передачи идей. Большинство из них ни к чему не призывает, но утверждает рево-

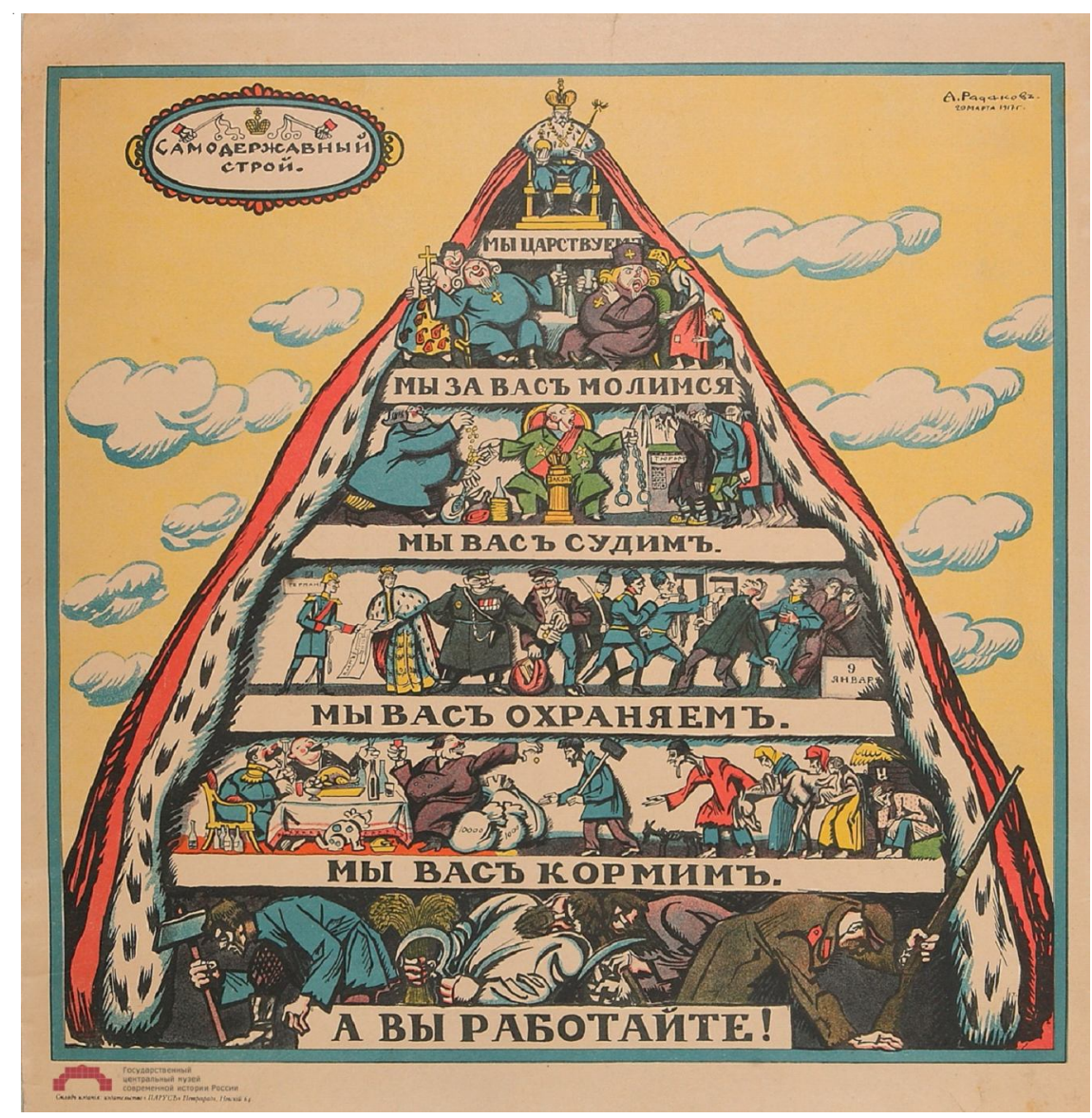

Рис. 4. Плакат «Самодержавный строй. Мы царствуем. Мы за вас молимся. Мы вас судим.

Мы вас охраняем. Мы вас кормим. А вы работайте!» А. Радакова (Петроград, изд-во «Парус», 1917 г.) 
люцию, демонстрирует радость, надежду на новую счастливую жизнь, новый справедливый миропорядок. Плакаты эмоционально включают зрителя. Есть такие, которые используют клише реалистичных газетных иллюстраций, но есть и те, которые совершают прорыв в использовании символов и в нахождении образов, что впоследствии будет успешно использоваться в массовой агитации («крестьянин», «рабочий», «солдат», «поп», «кулак», «генерал» и др.). Текст на плакате может быть и главным элементом, и подчиненным, и даже необходимой частью плаката. В плакатах ведутся поиски выигрышной цветовой гаммы и революционного символизма.

\section{Заключение}

На наш взгляд, основными причинами возрастания интереса к использованию политического плаката в 1917 г. является осознание потребности в оперативном, динамичном и массовом воздействии, информировании, а также потребности в удержании внимания и эмоциональном включении зрителя. Осознание ограниченности возможностей текстовой пропаганды открывает пространство для поиска новых визуальных форм воздействия. В результате сложился новый жанр политического плаката, обладающего своими неповторимыми особенностями формы и содержания. Среди них: ясность, непротиворечивость заключенной идеи, узнаваемость используемых образов, сюжетность, яркие цвета, минимизирование полутонов и теней, большеформатность и др.

В 1917 г. жанр политических революционных плакатов только начинал складываться, и многие особенности жанра советского политического плаката находились в разработке. Велся поиск символических визуальных форм и методов воздействия на массы. Отправной точкой служили рекламные плакаты, книжные (журнальные) иллюстрации, тропы, наработанные в изобразительном искусстве, которые пытаются переделать под новые политические задачи. Изображение подбиралось скорее из соображений «красивости», чем «убедительности», и могло быть не связано напрямую с идеей плаката. С точки зрения содержания ранние плакаты чаще повествуют или демонстрируют новый миропорядок, а не призывают к активным действиям. Конкретный призыв проголосовать встречается только в плакатах, посвященных предвыборной агитации. Ясность и непротиворечивость заключенных идей часто достигается за счет напечатанного на плакатах текста. Текст, как правило, выступает первичным по отношению к изображению и порой не удобен для чтения и восприятия. Ближе к концу революционного 1917 г. в плакатах начинает использоваться прием символизации и прием прорисовки сюжета. Персонажи становятся более близки и узнаваемы для реципиентов, вырабатываются характерные способы изображения тех или иных социальных акторов эпохи. Поиски не прошли даром - плакаты, посвященные революционной пропаганде, изданные ближе к концу года, находят необходимые выразительные символы и яркие образы. Была осознана необходимость говорить с народом, вовлеченным в революцию, на языке понятных и близких ему визуальных образов. Следующая задача, вставшая перед авторами плакатов, была посвящена поиску способов эффективной мотивации реципиентов на активные действия в революционной борьбе.

\section{ПРИМЕЧАНИЕ}

1 Работа выполнена при финансовой поддержке РФФИ в рамках научного проекта № 17-8301003 «Гражданская война в России в образах визуальной пропаганды: словарь-справочник».

\section{СПИСОК ЛИТЕРАТУРЫ}

1. Бабурина, Н. И. Россия - ХХ век. История страны в плакате / Н. И. Бабурина. - М. : Панорама, 2000. $-255 \mathrm{c}$.

2. Березовая, Л. Г. События 1917 года в художественном восприятии современников / Л. Г. Березовая // Октябрь 1917 года: взгляд из ХХІ века : сб. материалов Всерос. науч. конф. - М. : РИПО, 2007. C. 44-55

3. Вашик, К. Реальность утопии. Искусство русского плаката XX века / К. Вашик, Н. Бабурина. - М. : Прогресс-Традиция, 2005. - 422 с.

4. Катанян, В. А. Маяковский: Хроника жизни и деятельности / В. А. Катанян. - М. : Сов. писатель, 1985. -648 с. 
5. Кудин, П. А. Психология восприятия и искусство плаката / П. А. Кудин, Б. Ф. Ломов, А. А. Митькин. - М. : Плакат, 1987.-208 с.

6. Михайлин, В. Ю. Шершавым языком. Антропология советского политического плаката. Труды Лаборатории исторической, социальной и культурной антропологии. Вып. 20 / В. Ю. Михайлин, Г. А. Беляева, А. В. Нестеров. - Электрон. текстовые дан. - Режим доступа: https://www. researchgate.net/publication/284342550_SERSAVYM_ AZYKOM_Antropologia_sovetskogo_politiceskogo_ plakata (дата обращения: 09.11.2017). - Загл. с экрана.

7. Полонский, В. П. Русский революционный плакат / В. П. Полонский. - М. : ГИЗ, 1925. - 192 с.

8. Рашин, А. Г. Население России за 100 лет (1813-1913) : Статистические очерки / А. Г. Рашин. - Гл. 11. Грамотность населения России в XIX и начале ХХ вв. - М. : Гос. стат. изд-во, 1956. C. 284-318.

9. Требунских, М. С. Военная тематика в плакатном искусстве России первой половины ХХ в. / М. С. Требунских, Р. Ю. Волоснов. - Электрон. текстовые дан. - Режим доступа: https:/elibrary.ru/ item.asp?id=25519147 (дата обращения: 09.11.2017). Загл. с экрана.

\section{REFERENCES}

1. Baburina N.I. Rossiya $-X X$ vek. Istoriya strany $v$ plakate [Russia - the $20^{\text {th }}$ Century. History of the Country in the Poster]. Moscow, Panorama Publ., 2000.255 p.

2. Berezovaya L.G. Sobytiya 1917 goda v khudozhestvennom vospriyatii sovremennikov [The Events of 1917 in the Artistic Perception of Contemporaries]. Oktyabr 1917 goda: vzglyad iz XXI veka: sb. materialov Vseros. nauch. konf. [October of 1917: a View from the $21^{\text {st }}$ Century.
Collection of Materials of the All-Russian Scientific Conference]. Moscow, RIPO Publ., 2007, pp. 44-55.

3. Vashik K., Baburina N.I. Realnost utopii. Iskusstvo russkogo plakata XX veka [The Reality of Utopia. The Art of Russian Poster of the $20^{\text {th }}$ Century]. Moscow, Progress-Traditsiya Publ., 2005. 422 p.

4. Katanyan V.A. Mayakovsky: Khronika zhizni $i$ deyatelnosti [Mayakovsky: Chronicle of Life and Activity]. Moscow, Sovetskiy pisatel Publ., 1985. 648 p. 5. Kudin P.A., Lomov B.F., Mitkin A.A. Psikhologiya vospriyatiya $i$ iskusstvo plakata [Psychology of Perception and Poster Art]. Moscow, Plakat Publ., 1987. 208 p.

6. Mikhaylin V.Yu., Belyaeva G.A., Nesterov A.V. Shershavym yazykom. Antropologiya sovetskogo politicheskogo plakata. Trudy Laboratorii istoricheskoy, sotsialnoy i kulturnoy antropologii. Vipusk 20 [With the Scratchy Tongue. Anthropology of the Soviet Political Poster. Proceedings of the Laboratory of Historical, Social and Cultural Anthropology. Issue 20]. URL: https://www. researchgate.net/publication/284342550_ SERSAVYM_AZYKOM_Antropologia_sovetskogo_ politiceskogo_plakata (accessed November 9, 2017).

7. Polonskiy V.P. Russkiy revolutsionnyy plakat [Russian Revolutionary Poster]. Moscow, GIZ Publ., 1925. $192 \mathrm{p}$.

8. Rashin A.G. Naseleniye Rossii za 100 let (1813-1913). Statisticheskiye ocherki. Glava 11. Gramotnost naseleniya Rossii $v$ XIX i nachale XXvv. [The Population of Russia for 100 Years (1813 - 1913). Statistical Essays. Chapter 11. Literacy of the Russian Population in the $19^{\text {th }}-$ early $20^{\text {th }} \mathrm{cc}$. $]$. Moscow, Gos. stat. izd-vo, 1956, pp. 284-318

9. Trebunskikh M.S., Volosnov R.Yu. Voennaya tematika $v$ plakatnom iskusstve Rossii pervoy poloviny $X X v$. [Military Themes in the Russian Poster Art in the First Half of the $20^{\text {th }}$ Century]. URL: https://elibrary.ru/ item.asp?id=25519147 (accessed November 9, 2017).

\section{Information about the Author}

Nadezhda A. Zinovyeva, Candidate of Sociological Sciences, Associate Researcher, Sociological Institute of the Federal Sociological Research Center of RAS, 7-ya Krasnoarmeyskaya St., 25/14, 190005 Saint Petersburg, Russian Federation, n.zinoveva@socinst.ru.

\section{Информация об авторе}

Надежда Андреевна Зиновьева, кандидат социологических наук, ассоциированный научный сотрудник, Социологический институт Федерального научно-исследовательского социологического центра РАН, 7-я Красноармейская ул., 25/14, 190005 г. Санкт-Петербург, Российская Федерация, n.zinoveva@socinst.ru. 